\title{
Economics of forest bioeconomy: new results
}

\author{
Jenni Miettinen and Markku Ollikainen
}

\begin{abstract}
We examine the emerging forest bioeconomy as an integrated, multi-product industrial ecosystem, where the traditional pulp mills allocate the use of side streams to independent biochemical companies manufacturing bioproducts in the vicinity of the pulp mills. Biochemical companies benefit from the proximity by receiving wood-based side streams at lower costs, and at the same time, pulp mills benefit from having a new source of revenue from selling side streams. We focus on the economic interaction between the pulp mill and the biochemical company, and we study the impacts on the use of wood and profits under perfect and imperfect competition. We demonstrate that the new industrial ecosystem uses more wood than traditional pulp mills, but depending on the side stream, it may promote cascading use of wood-based side streams.
\end{abstract}

Key words: biochemical companies, cascade use of wood, industrial ecosystem, pulp mills, tall oil.

Résumé : Nous examinons la bioéconomie forestière émergente comme un écosystème industriel intégré multiproduit, où les usines de pâte à papier traditionnelles attribuent l'utilisation des produits secondaires à des entreprises biochimiques indépendantes qui élaborent des bioproduits et sont situées à proximité de l'usine de pâte. Les entreprises biochimiques profitent de cette proximité en obtenant les résidus à base de bois à un coût moindre et, par la même occasion, les usines de pâte à papier bénéficient d'une nouvelle source de revenus grâce à la vente de produits secondaires. Nous mettons l'accent sur l'interaction économique entre l'usine de pâte à papier et l'entreprise biochimique, et nous étudions les impacts sur l'utilisation du bois et les bénéfices en situations de concurrence parfaite et imparfaite. Nous démontrons que le nouvel écosystème industriel utilise plus de bois que les usines de pâte à papier traditionnelles, mais selon le flux de produits secondaires cela peut promouvoir l'utilisation en cascade de produits secondaires à base de bois. [Traduit par la Rédaction]

Mots-clés : entreprises biochimiques, utilisation en cascade du bois, écosystème industriel, usine de pâte à papier, tallöl.

\section{Introduction}

New drivers, such as climate and energy policies, technological possibilities for generating new products, industrial globalization, and megatrends of services and digitalization, are changing the business environment in the forest sector (Nabuurs et al. 2015). This development provides new possibilities and challenges to promote the shift from the traditional forest industry towards a forest bioeconomy. The shift to bioeconomy is generally identified as manufacturing a large set of new and high-value-added products alongside old products and a consequential diversification of wood-based businesses (Ollikainen 2014). Furthermore, a forest bioeconomy is assigned to find solutions to several sustainability goals, such as replacing non-renewable resources, maintaining biodiversity, and increasing resource efficiency (e.g., Antikainen et al. 2017; Priefer et al. 2017; Winkel 2017).

In the literature, the notion of biorefinery is often used to provide a conceptual understanding of new ways of producing multiple goods from wood biomass (Christopher 2013). However, the economic content of the new forest bioeconomy concept is perhaps better understood and modelled as an integrated multiproduct industrial ecosystem. The traditional pulp mills allocate other biomass-based production lines to separate companies, which sell their products directly to consumers or producers.
This trend is evident, especially in Finland and Sweden, where the most significant new softwood pulp investments have been made. The new plants are called "bioproduct mills" in Finland, as the business model is based on a network of companies utilizing side streams from pulp mills. ${ }^{1}$ Alternatively, the traditional forest companies may add new production lines and produce the new value-added bioproducts by themselves. For example, Södra started biobased methanol production in Mönsterås (Sweden) in 2020, and UPM is constructing its new biochemicals facility in Leuna (Germany).

The recent emergence of integrated multi-product industrial ecosystems is based on the fact that the most efficient path towards new value-added products relies on the traditional forest companies. These companies buy and efficiently transfer wood from forests to pulp mills, providing wood waste and various side streams, such as biosludge, tall oil, or lignin, for biochemical and other companies. As a result, the biochemical companies benefit from reduced material costs, and the pulp mills, in turn, have a new revenue source from selling side streams as an alternative to using them for energy. However, while the literature on the material flows and production in the new industrial ecosystem is voluminous (e.g., Wenger and Stern 2019), treatises on the economic dimensions of this new system are scarce.

Received 20 June 2021. Accepted 25 October 2021.

J. Miettinen and M. Ollikainen. Department of Economics and Management, University of Helsinki, Latokartanonkaari 5, FI-00014 University of Helsinki, Finland.

Corresponding author: Jenni Miettinen (email: jenni.miettinen@helsinki.fi).

(C) 2021 The Author(s). This work is licensed under a Creative Commons Attribution 4.0 International License (CC BY 4.0), which permits unrestricted use, distribution, and reproduction in any medium, provided the original author(s) and source are credited.

${ }^{1}$ Metsä Fibre Äänekoski bioproduct mill started its operations in 2017 and Metsä Fibre Kemi bioproduct mill was announced in 2021. 
It is interesting to examine how the economic interaction between pulp mills and the new biochemical companies occurs in the emerging industrial ecosystem. For example, how does the possibility of producing energy from side streams impact a pulp mill's demand for pulpwood? How does the possibility of selling side streams to a biochemical company affect the pulp mill's production choices? Given the large pulp companies and new smaller companies manufacturing new bioproducts from side streams, is there a danger for imperfect competition, and how do these imperfections distort the use of side streams?

To address these topical issues of emerging bioeconomy solutions, we develop a formal economic model of the new industrial ecosystem and apply it numerically to the Finnish forest sector. The model's core is the interaction between a pulp mill and a biochemical company, basing their production on wood biomass and its side streams. The pulp mill brings the wood to the industrial ecosystem and receives revenue from pulp production and selling side streams of production, such as bark, lignin, and biosludge. The biochemical company then makes new and high-value-added products from the side streams. In addition, modern pulp mills produce more energy than they need in their production process, making them sellers of energy (both electricity and heat). Thus, the pulp mill can either use the side streams of wood in its energy production or provide part of the side streams to the biochemical company.

Our model consists of one pulp mill and one biochemical company to analyze the new industrial ecosystem sharply. We vary their interaction, assuming first perfect competition and then introduce market imperfections in two forms: the market power is given both upstream and downstream. Furthermore, we briefly focus on another type of imperfection, the risk concerning the adequacy of the raw material supplied to the biochemical company. Most of the analysis focuses on the behaviour of the pulp mill, around which the cascading use of wood-based side stream is built. Based on the theory, we build a numerical model to examine the magnitudes of impact and focus on detailed components of the model.

Literature on forest bioeconomy is developing rapidly. However, it has primarily focused on technical or material use issues and contained significantly fewer studies on economics, market implications, and policy designs (e.g., Söderholm and Lundmark 2009; Kangas et al. 2011; Gan 2013; Giurca and Späth 2017; Majumdar et al. 2017; Purkus 2017, Hurmekoski et al. 2018; Lundmark et al. 2021). Furthermore, most of the studies on forest bioeconomy focus on biofuels and bioenergy. Only a few examine the role of biochemicals, biomaterials, and bioproducts (Bauer et al. 2017; Dessbesell et al. 2017; Wenger and Stern 2019; Jonsson et al. 2021), even though the new high-value-added products will probably be invented for uses of wood biomass other than biofuels (Hurmekoski et al. 2018). This emphasis on biofuels contrasts with experts' position that only woodbased biomass that cannot be utilized for higher-value-added products should be used in bioenergy or biofuel production (Hämäläinen et al. 2011).

An extensive set of previous quantitative modelling literature on forest biorefineries consists of supply chain design and optimization studies, which primarily focus on bioenergy and biofuels (e.g., Machani et al. 2014; Dessbesell et al. 2017; Daya and Nourelfath 2019). Higher-value-added production options, especially biochemicals, are less examined in supply chain and techno-economic assessment studies (e.g., Mansoornejad et al. 2010, 2013; Dessbesell et al. 2018; Elaradi et al. 2021). Dansereau et al. (2014) conclude in their review that it is vital for forest biorefineries' competitiveness to produce at least one differentiable added-value product and to assess the bioproduct portfolio according to supply chain design and management methodologies. As companies' future success will depend increasingly on environmental performance in addition to the economic profitability of the supply chain, green supply chain management provides a suitable tool for decision making. It combines the assessment of environmental impacts with economic and operational performance analysis (Daya and Nourelfath 2019).
Promoting the cascading use of wood is essential for the notion of bioeconomy as a provider of several environmental, social, and economic benefits (Jarre et al. 2020; Thonemann and Schumann 2018). In their review, Jarre et al. (2020) identify responses to policy, market, technical implementation, environmental effects, and stakeholder involvement as the main factors promoting cascading use of wood. Quantitative studies on the environmental impacts of cascading use of wood typically apply life cycle assessment (Jarre et al. 2020; Thonemann and Schumann 2018). A still somewhat limited number of life cycle studies have focused on alternative uses of pulp mill's side streams, such as tall oil, lignin, and biosludge (Cashman et al. 2015; Aryan et al. 2019; Bajwa et al. 2019; Culbertson et al. 2016; Mohammadi et al. 2019a, 2019b; Secchi et al. 2019; Hermansson et al. 2019, 2020). Studies on the tall oil industry have compared the use of tall oil either in biodiesel or in the pine chemicals industry (Cashman et al. 2015; Aryan et al. 2019). Bajwa et al. (2019) discuss the possibilities of lignin-derived products to improve both the profitability of the pulp and paper companies and their environmental performance compared to fossil-based products. Mohammadi et al. (2019a, 2019b) analyze the alternative uses of pulp and paper mill biosludge and their environmental impacts. These studies indicate that the cascading use of side streams may lead to better environmental performance (Cashman et al. 2015; Aryan et al. 2019; Bajwa et al. 2019; Culbertson et al. 2016; Mohammadi et al. 2019a, 2019b). However, as in the case of lignin, for example, the allocation method highly impacts the results of life cycle analyses (Secchi et al. 2019; Hermansson et al. 2020; Wenger et al. 2020). Furthermore, Jarre et al. (2020) point out that the economic competitiveness and environmental performance between energy and material uses of wood are uncertain, as they depend on several factors and on the chosen evaluation criteria.

Previous work indicates that biorefineries still have several challenges in answering the promise for new value-added products and improved sustainability (Temmes and Peck 2020). The new woodbased products have been estimated to increase the demand for wood (Hurmekoski et al. 2018). Thus, environmental concerns exist related to the forest sector's expected increase in wood use (Kumar et al. 2021). At the same time, many countries have increased biofuel and bioenergy production to replace fossil fuels in energy production (Kangas et al. 2011). The change to biofuel and bioenergy production will also increase demand for wood biomass. The increased use of forest biomass, especially in the energy sector, has been a significant factor in increasing competition for wood among buyers (Lundmark and Olsson 2015). Previously, at the European Union (EU) level, it has been estimated that the wood resources might not even satisfy the demand for wood in the future due to EU policies promoting renewable energy targets (Jonsson 2013).

Our work differs from previous literature in that we provide a comprehensive economic analysis of forest bioeconomy as an emerging industrial ecosystem. First, we characterize the new system, explore its properties, and develop a numerical model to assess the established properties of the model quantitatively. The rest of the study is organized as follows. In the next section, we present the theoretical framework applied in this study. Then, we develop the numerical application in section 3. Finally, the discussion and conclusions are presented in section 4 .

\section{Economics of forest bioeconomy}

We now develop a forest bioeconomy model focusing on an industrial ecosystem consisting of a traditional pulp mill and a new biochemical company starting with perfect competition. The model is then extended to cover imperfect competition.

\subsection{The setup: forest bioeconomy as an industrial ecosystem}

Consider two companies, a pulp mill and a biochemical company, the latter manufacturing its products using wood-based side streams in the vicinity of the pulp mill. Choosing a location close to the pulp mill decreases the biochemical company's costs, 
but fixing the location also makes it vulnerable to possible changes in the supply of wood-based side streams. Thus, benefits, on the one hand, and risks, on the other hand, characterize the forest bioeconomy as an industrial ecosystem - features identified in many other industries. To reduce these risks, the pulp mill and the biochemical company may enter a long-term contract securing delivery of side streams. Such a contract would dictate the amounts and prices of trade under some flexibility. ${ }^{2}$

We start downstream with the use of wood biomass by an independent biochemical company. It is an integral part of the new industrial ecosystem located in the vicinity of the pulp mill. To keep the analysis clear and without loss of generalization, we postulate that only one company produces biochemical products from each side stream. The company uses two inputs in its production: side streams from the pulp mill and energy. Let the amount of wood-based side stream from the pulp mill be $m=\eta x$, where $\eta$ indicates the share of wood-based side stream sold to the biochemical company from the pulp mill, and $x$ denotes the amount of pulpwood bought for pulp production. Let the production process be defined by a well-behaving concave production function $g\left(m, e_{b}\right)$, where $e_{b}$ denotes energy used by the biochemical company. Finally, let the price of the biochemical product be $P$, the cost of the woodbased side stream $c$, and the price of energy $\varphi$.

The biochemical company maximizes its profits by choosing two inputs: the amount of side stream and energy:

(1) $\quad J=P g\left(m, e_{b}\right)-c m-\varphi e_{b}$

We return later to the specific features of profit maximization. First, however, we note that solving the profit maximization problem results in the derived demand for side streams, $m^{d}=\eta x^{d}(P, c, \varphi)$. The demand function depends positively on the price of the biochemical product and negatively on input prices (details of the biochemical company will be scrutinized later). This demand enters the profit maximization problem of the pulp mill.

The pulp mill uses three inputs, pulpwood, energy, and chemicals, to produce pulp. Pulpwood is the main input in production. The amount of pulpwood bought from the timber market is $x$. Pulp production technology requires debarking the trees; also, a part of biomass (the so-called zero fibre) is unusable in pulp production. We denote the technologically fixed share of pulpwood usable in pulp production by $\varepsilon x$ with $0<\varepsilon<1$. The production process requires energy, denoted by $e_{p}$. The pulp production technology defines a concave production function $f\left(\varepsilon x, e_{p}\right)$. We assume that the production function is well-behaving and continuously differentiable with positive first derivatives $\left(f_{x}>0\right.$ and $\left.f_{e_{p}}>0\right)$ and negative second derivatives $\left(f_{x x}<0\right.$ and $\left.f_{e_{p} e_{p}}<0\right)$.

The share of wood fibre not usable in pulp production is $(1-\varepsilon) x$. This amount can be used to produce renewable energy in the pulp mill or sold to biochemical companies as a raw material for biochemical production. To examine how the pulp mill allocates the side stream between these two alternatives, we denote the share of the side stream sold to the biochemical company by $\eta$ with $0 \leq$ $\eta \leq 1$, indicating the corner solutions are possible in principle. Thus, the share of pulpwood used in energy production in the pulp mill is $\hat{x}=(1-\varepsilon)(1-\eta) x$. We describe the amount of energy produced in the pulp mill by a production function $\hat{e}(\hat{x})$, which is concave. Typically, pulp mills produce more energy than they need in their pulp production, making them energy sellers. The company's energy sales are defined by the difference between produced and consumed energy: $\hat{e}(\hat{x})-e_{p}$.
For simplicity, we assume that chemical costs are proportional to the amount of pulpwood used in production, $\sigma x$, and the unit price of chemicals is $k$. Let the price of pulp be $p$, price of pulpwood by $w$, price of energy by $\varphi$, and price of side stream sold to the biochemical company by $c$. The profit maximization problem of the pulp mill is then as follows:

$$
\pi=p f\left(\varepsilon x, e_{p}\right)-w x+\varphi\left[\hat{e}(\hat{x})-e_{p}\right]-k \sigma x+c \eta x
$$

Equation 2 is seemingly simple, yet it allows an examination of the three key choices that the pulp mill typically does in real market conditions. ${ }^{3}$ We now turn to the formal analysis of both companies in the emerging industrial ecosystem of the forest bioeconomy.

\subsection{A pulp mill in a perfect market: demand for wood, cascading use versus energy production}

Even though the pulp mill faces a demand function for side streams and may have market power, we assume in this section that it operates as in a perfect market and takes the price of side streams as given. The price of pulp, determined in the international markets, is exogenous to the pulp mill. Under these assumptions, the economic problem of the pulp mill is to choose the use of pulpwood and energy inputs and allocate the wood-based side streams between energy production and sales to the biochemical company:

$$
\pi=p f\left(\varepsilon x, e_{p}\right)-w x+\varphi\left[\hat{e}(\hat{x})-e_{p}\right]-k \sigma x+c \eta x
$$

The use of pulpwood, $x$, energy, $e_{p}$, and share of side stream sold to a biochemical company, $\eta$, are implicitly defined by

$$
\begin{array}{ll}
x: & p f_{x} \varepsilon-w+\varphi \hat{e}_{x}(1-\varepsilon)(1-\eta)-k \sigma+c \eta=0 \\
e_{p}: & p f_{e_{p}}-\varphi=0 \\
\eta: & -\varphi \hat{e}_{\eta}+c=0
\end{array}
$$

We start the interpretation with eqs. 5 and 6 as they are more straightforward to analyze. Equation 5 defines the use of energy in production by requiring that the value of marginal product equal the price of energy. Optimality condition (eq. 6) indicates that the pulp mill increases the share of the side stream sold to the biochemical company to the point where the lost value of marginal energy product equals the revenue (price) from selling that share to the biochemical company.

Equation 4 exhibits many interesting components and provides new insights into the forest bioeconomy. Therefore, we interpret this condition in subsequent steps. Suppose first that the pulp mill would neither produce energy from side streams nor sell side stream to the biochemical company. Setting $\hat{e}(\hat{x})=0$ and $c=0$ gives as the optimality condition: $p f_{x} \varepsilon=w+k \sigma$. Interpretation is obvious - the use of pulpwood is increased to a point where the value of marginal product equals the price of wood and the marginal cost of chemicals. This condition reflects the conventional analysis of any company using inputs in production under the technologically fixed share of usable wood in production. ${ }^{4}$

We next add the possibility of producing energy from side streams of the chemical process. This addition leads to eq. 7 , where we, for expositional purposes, shift the additional revenue to the cost side to reduce the costs:

\footnotetext{
${ }^{2}$ Please note that the pulp mill could start to manufacture biochemical products by itself, thus entering other markets than the pulp market. In this case, pricing between the production lines or divisions would be based on pricing under perfect market conditions.

${ }^{3}$ The analytical model omits labor and capital costs for simplicity, but we include labor and capital costs in the numerical analysis.

${ }^{4}$ This optimality condition implicitly assumes free disposal of waste streams, for instance, in landfills. While many companies traditionally have their own landfills, there is a long tradition of using the most valuable and important side streams. Nevertheless, the case of free disposal provides the theoretical baseline for our analysis.
} 


$$
\text { (7) } \quad p f_{x} \varepsilon=w+k \sigma-\varphi \hat{e}_{x}(1-\varepsilon)
$$

The right-hand side of eq. 7 contains the marginal revenue from energy production, which reduces the costs of the two inputs. For the given value of the marginal product, the decrease in the net costs of the wood input boosts the use of wood to take full advantage of the possibility of earning some additional revenue from selling renewable energy. Thus, we find that the production of renewable energy from side streams tends to increase the use of wood.

In the spirit of circular economy, we now introduce the possibility that the pulp mill sells side streams to the biochemical company and receives a constant price $c$ for each unit sold. Given that a concave function characterizes the pulp mill's energy production, an interior solution emerges where the pulp mill produces energy and sells side streams simultaneously. The interior solution leads to the following re-expression of eq. 4 for the choice of pulpwood:

$$
p f_{x} \varepsilon=w+k \sigma-\varphi \hat{e}_{x}(1-\varepsilon)(1-\eta)-c \eta
$$

The right-hand side now contains a term, $c \eta$, tending to reduce further the costs of using pulpwood in production, but this share slightly reduces marginal revenue from energy production. By eq. 6 and concavity of energy production, the net result is, however, increased use of pulpwood relative to the previous cases. This outcome provides our second new finding for a forest bioeconomy.

Figure 1 illustrates the impacts of input prices, net of marginal revenue from energy, and sales of side streams on the use of pulpwood in the pulp mill. It assumes an interior solution for all decision variables introducing them in a row, starting with the case of no side streams and introducing then energy use of side stream followed by saleable side stream. The value of marginal product function of pulpwood is downward-sloping in the use of pulpwood, $x$. The vertical axis describes the input prices $(w+k \sigma)$ from which the marginal revenue from energy and sales of side streams are subtracted. The determination of pulpwood use can be read on the horizontal axis as gradually increasing amounts of pulpwood use.

We will assess the quantitative effects relating to the use of side streams using a numerical model in section 3 . We now turn to other properties of the model.

Given that the second-order conditions hold due to concavity assumptions, the first-order conditions implicitly define the optimal use of pulpwood and energy and the allocation of woodbased side streams between energy production and sales to the biochemical company. The dependence of this choice on exogenous variables can be examined using comparative statics. We are especially interested in determining how prices of pulp, energy, and side stream, as well as input prices, impact the optimal choices of the pulp mill. We compile the results in Table 1.

As expected, the price of pulp has a positive impact on the use of wood, as it increases the profitability of pulp production. Its impact on energy production is generally ambiguous, as is well known from production theory. In the usual case, assuming that the inputs are complements, the sign would be positive. The effect of pulp price on the share of sold side stream is positive, because the mill uses more pulpwood to increase pulp production.

An increase in the energy price affects all decision variables ambiguously. However, the impact is natural, as energy plays a double role as a production factor and a source of revenue. When the energy price increases, for complements, the use of energy decreases, but at the same time, the profitability of energy production from side streams increases. Depending on which one of these opposing effects dominates, the effects are either positive or negative. A higher price of side streams has a positive effect on the use of wood, use of energy, and the share of sold side stream, as it increases the profits of the pulp mill by boosting pulp production.

The price of pulpwood has a negative effect on the use of wood and energy, and the share of sold side stream. Energy and pulpwood are complements in pulp production, which explains the negative
Fig. 1. Impact of input prices and additional revenue from energy and side stream selling on the use of pulpwood in the pulp mill. [Colour online.]

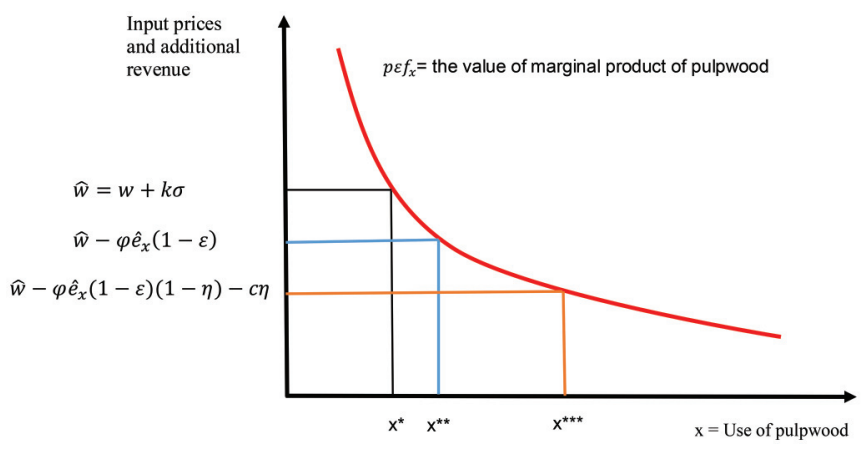

Table 1. Comparative statics of the model.

\begin{tabular}{llll}
\hline & & & Share of sold \\
Exogenous variable & Use of pulpwood & Use of energy & side stream \\
\hline Pulp price & + & $?$ & + \\
Energy price & $?$ & $?$ & $?$ \\
Price of side stream & + & + & + \\
Price of pulpwood & - & - & - \\
Price of chemicals & - & - & - \\
\hline
\end{tabular}

impact on energy use: the higher price of pulpwood decreases production and energy use. As production decreases, the amount of side streams decreases, and the pulp mill sells less side stream to the biochemical company and uses more in its own energy production. An increase in the price of chemicals decreases the use of all endogenous variables similarly to the price of pulpwood.

We condense the most important implications of the findings of the model in proposition 1.

Proposition 1. A forest bioeconomy as an industrial ecosystem, comprising pulp mills and biochemical companies, supplies new biochemical products and renewable energy from wood residuals and side streams in addition to the main product, pulp. Under perfect competition, this industrial ecosystem uses more pulpwood than it would use without the utilization of side streams. At the same time, it promotes a more efficient cascading use of side streams.

How does proposition 1 relate to the postulated goals and promises of a forest bioeconomy? Incentives for using more wood are stronger than in the traditional forest industry. Increasing demand for pulpwood creates additional pressure on the use of forests. The impacts on biodiversity are not, however, evident. The pulp mill buys most of the pulpwood from thinnings and final fellings. Thus, the overall effect of increased demand for pulpwood on biodiversity depends on multiple issues, such as how significant the increase in pulpwood demand is, what the relative shares of pulpwood from thinnings and final fellings are, how increasing timber prices affect the levels of final fellings, and most of all, what is the forest management regime (such as continuous cover or even-aged forest management with clearcuts). Furthermore, measures and instruments used to promote biodiversity modify all forest management regimes (Hetemäki et al. 2017). Furthermore, increasing demand for pulpwood reduces the forest carbon sink on the one hand, but on the other hand, channelling biomass to a further cascading use instead of burning it is beneficial climate-wise and also promotes a circular economy. All in all, the previous discussion shows that while promoting cascading use of wood and reducing fossil fuels in energy production, a forest bioeconomy may face trade-offs 
between increased use of wood and biodiversity, and between energy and biochemical production based on side streams.

The economic functioning of the industrial ecosystem may not even be as harmonious as the previous analysis suggests. The questions of market power and shortages of raw material for the biochemical company may seriously hinder the development of the industrial ecosystem. We next focus on these issues.

\subsection{Market imperfections in the forest bioeconomy}

The industrial ecosystem may not be perfect. Market imperfections may exist either upstream or downstream, and more probably so upstream. In addition, the amount of wood-based side stream may be volatile due to changes in market prices of pulp, wood, and energy. Furthermore, the wood-based side stream may not be sufficient for the biochemical company's production if the demand for its product increases. The only way of expanding production in such circumstances will be to import raw material from elsewhere if that option is feasible. This section provides a brief analysis of these imperfections.

\subsubsection{Pulp mill as a monopoly in side stream markets}

A large pulp mill may easily have market power in the side stream markets, making it a monopoly in that market while it remains competitive in the pulp markets. In this case, the pulp mill faces the demand for its wood-based side stream and can choose either its price or quantity but not both. The inverse demand function for the side stream, $\eta x$, by the biochemical company can be defined as $c(\eta x)$. We re-write the profit function of the pulp mill to reflect the demand function:

$$
\pi=p f\left(\varepsilon x, e_{p}\right)-w x+\varphi\left[\hat{e}(\hat{x})-e_{p}\right]-k \sigma x+c(\eta x) \eta x
$$

The optimal choice of the monopolist pulp mill is characterized by

$$
\begin{aligned}
x: \quad p f_{x} \varepsilon-w+\varphi \hat{e}_{x}(1-\varepsilon)(1-\eta)- & k \sigma+c(\eta x) \eta \\
& +c_{\eta x}(\eta x) \eta^{2} x=0
\end{aligned}
$$

$$
\begin{array}{ll}
e_{p}: & p f_{e_{p}}-\varphi=0 \\
\eta x: & -\varphi \hat{e}_{\eta x}+c_{\eta x}(\eta x) \eta x+c(\eta x)=0
\end{array}
$$

Energy use in eq. 11 remains qualitatively similar to that under perfect competition, but the two other optimality conditions exhibit new features. We start interpreting the optimality conditions by looking at eq. 12 , the decisions to sell side stream to the biochemical company. Relative to eq. 6 , the optimality condition contains an additional term $c_{\eta x}(\eta x) \eta x$ implying that eq. 12 contains marginal revenue (MR) from selling side streams to the biochemical company defined by $\mathrm{MR}=c_{\eta x}(\eta x) \eta x+c(\eta x)$. Thus, the pulp mill sells side streams up to the point where the marginal revenue from the last unit sold equals the lost value of the marginal product of side stream in its energy production, that is, marginal cost defined by $\varphi \hat{e}_{\eta x}$. Relative to the perfect competition, the pulp mill reduces the supply of side streams to the biochemical company and shifts a higher share to its energy production to increase the selling price.

The use of pulpwood in eq. 10 differs from that under perfect competition, and we re-express it in a similar way as before:

$$
p f_{x} \varepsilon=w+k \sigma-\varphi \hat{e}_{x}(1-\varepsilon)(1-\eta)-\eta\left[c(\eta x)+c_{\eta x}(\eta x) \eta x\right]
$$

The last bracket term in eq. 13 is simply $\eta \mathrm{MR}$, indicating that the marginal revenue from the side stream impacts the use of pulpwood as a marginal opportunity cost. As other terms in eq. 13 are the same as in perfect competition, the use of pulpwood is lower than under perfect competition. As the pulp mill reduces the supply of side stream to the biochemical company to increase the selling price, it also reduces demand for pulpwood.

\subsubsection{Biochemical company: material shortages and market power}

Consider next the biochemical company. We keep the notation provided in section 2.1 but include a possibility of buying similar raw material (as a wood-based side stream) from other sources. In this case, the biochemical company must pay the price and transport cost for this item, denoted by $\hat{c}$ (if no import is needed, costs are $c$ ). We denote the amount of wood-based side stream from the pulp mill by $\eta x$ and additional raw material from another source by $z$. Thus, to allow for importing wood-based side stream, the total amount of side stream used is $m=\eta x+z$. The profits of the biochemical company, denoted by $J$, are given by

(14) $J=\operatorname{Pg}\left(m, e_{b}\right)-\hat{c} m-\varphi e_{b}$

leading to the first-order conditions:

$$
\begin{aligned}
& \text { m: } \quad P g_{m}-\hat{c}=0 \\
& \text { e: } \quad \operatorname{Pg}_{e_{b}}-\varphi=0
\end{aligned}
$$

Interpretation of both conditions is conventional: the value of marginal product equals the input price.

Two twists of eqs. 15 and 16 are worth looking at in this problem. First, a shortage in the supply of side streams, and second, the unlikely but still possible case wherein the biochemical company has market power. We start with the case of shortage by looking more closely at the properties of eq. 15 . Consider the case in which importing raw material elsewhere would not be possible and evaluate eq. 15 by setting $z=0$. Given concavity of production function, this would lead to

$$
\text { (17) }\left.\quad P g_{m}\right|_{z=0}-\hat{c}>0
$$

Thus, the biochemical company is not producing at the optimal level and would increase its profits by increasing the use of side streams in its production. There are many reasons why this possibility would emerge. First, pulp production has historically been sensitive to business cycles with periods of booms and recessions, which are potential conditions for shortages. Second, demand for the produced biochemical product may expand beyond the expected. Third, both high transport costs and legislation governing the possibilities of transporting side streams may prevent the use of the planned additional raw material. Fourth, policies might also create incentives for the pulp mill to utilize side streams for other uses, such as biodiesel production, creating a shortage of raw material and need for imports (Cashman et al. 2015). Figure 2 illustrates these possibilities. If the biochemical company can buy enough raw material from the pulp mill at price $c$, it would use an amount of $m^{* * *}=\overline{\eta x}$. If there is a shortage of raw material, the company imports some material from outside at higher costs. Under a higher cost $\hat{c}$, the optimal amount of side stream $m^{* *}=\eta x+z$, with $m^{* *}<m^{* * *}$. But if $z=0$, the amount of side stream that the biochemical company buys only $m^{*}=\eta x$, and the excess demand (Ed) caused by material shortage is shown in Fig. 2.

If the biochemical company had market power concerning buying the wood-based side stream, it would face the (inverse) supply function, expressed as $c(\eta x)$ with $c_{\eta x}(\eta x) x>0$, indicating that if the biochemical company wants to buy more, it should 
Fig. 2. The impact of the shortage of raw material on the choice of the profit-maximizing biochemical company. [Colour online.]

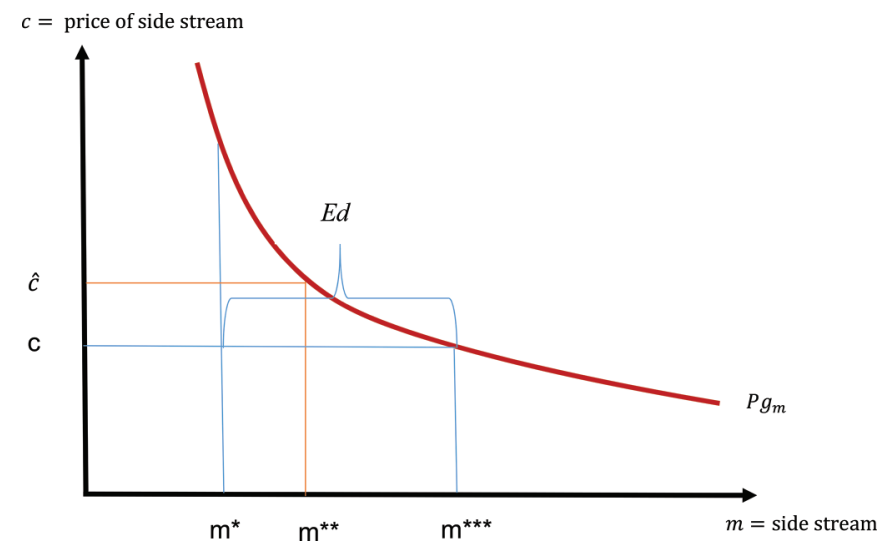

pay a higher price for side streams. The target function of the biochemical company reads

$$
J=\operatorname{Pg}\left(\eta x, e_{b}\right)-c(\eta x) \eta x-\varphi e_{b}
$$

While the optimality condition for energy use remains qualitatively the same as before, the demand for side stream is determined by

$$
\eta x: \quad \operatorname{Pg}_{\eta x}-\left[c(\eta x)+c_{\eta x}(\eta x) \eta x\right]=0
$$

This condition is the classical monopsony choice: the value of the marginal product of the side stream is set equal to its marginal buyer cost $(\mathrm{MBC})$ defined by $\mathrm{MBC}=c(\eta x)+c_{\eta x}(\eta x) \eta x$. Thus, the monopsonistic biochemical company reduces its demand for side streams to reduce the price it has to pay to the pulp mill for the side stream. As the demand for side streams is reduced by Table 1, the pulp mill reduces the use of pulpwood, energy, and side stream sales to the biochemical company, as the biochemical company used market power to reduce the price below the competitive price.

We collect the main findings concerning imperfect competition to Proposition 2.

Proposition 2. Market imperfections of the industrial ecosystem of forest bioeconomy showing up either in monopoly or monopsony behaviour lead to a lower cascading use of wood-based side streams and increase their use in energy production. At the same time, both cases decrease the demand for pulpwood.

Proposition 2 shows that the previously identified trade-offs also prevail under imperfectness: while the use of pulpwood decreases, which may improve biodiversity (under the qualification presented above), the forest bioeconomy fails to fully promote cascading use of timber, which would be beneficial for the climate. In more general terms, there is a loss of welfare, measured by the sum of producers' (pulp mill) and buyers'/consumers' (biochemical company) surplus and environmental impacts due to imperfectness relative to the case of perfect competition in the forest bioeconomy. How significant the welfare loss is, is an empirical question. Nevertheless, our analysis suggests that even imperfect markets in a forest bioeconomy provides a welfare improvement compared to the case where all wood-based side streams are either placed on landfills or used for energy only.
We next turn to examine how the features outlined by the theory appear between a pulp mill and biochemical company for some selected examples of wood-based side streams.

\section{A numerical analysis of forest bioeconomy}

We build our numerical model using some typical side streams from the pulp mills in the Finnish forest industry. They include lignin, biosludge, and tall oil, which the pulp mill may use in energy production or sell to a biochemical company. Many intermediate products (e.g., detergents, resins, and preservatives) can be made from lignin. However, it is currently most often used for energy in pulp mills (Hurmekoski et al. 2018; Volama 2012). Biosludge is used mainly as an energy source in Finland, even though it is not well suited to energy production due to its moisture content (Moring et al. 2013; Pöykiö et al. 2018). One alternative is to place it in a landfill (Mohammadi et al. 2019a). However, biosludge from the pulp mill can be utilized as a fertilizer or a material for soil amendment (Pöykiö et al. 2018). Tall oil has been used for decades as an input in the production of bio-based chemicals. It also illustrates alternative and competing use of side streams. European Union policies promote biofuel production, providing the possibility of using tall oil for biodiesel (EU Directive 2015/1513; European Parliament and of the Council 2015). This competing use may create a shortage of tall oil material for the tall oil industry that produces higher-value-added products from tall oil, according to the cascading use of side streams.

Since data are too limited for a comprehensive analysis, we are obliged to restrict the analysis to the case of perfect competition on both sides of the forest bioeconomy. We focus on both the shortterm and long-term profits of the pulp mill. The former case helps us to identify the differences concerning profits when side streams are either used in the pulp mill's energy production or sold as a side stream. The latter case shows how pulp mills perform in the forest bioeconomy outlined by the theory. Finally, we focus especially on tall oil and its use in the pine chemical industry.

\subsection{Cascading use of side streams: the pulp mill}

\subsubsection{Data and parameters}

The key variables of the theoretical model are the prices of pulp and productive inputs and the side streams. Furthermore, we need information on input use and production of pulp and side streams. The parameter values are given in Table 2 . Data on the costs and profitability of the pulp mills are scarce (Korpunen et al. 2012), and we have collected data from multiple sources. Thus, some inconsistency is possible in the way parameter values are determined in each source. This does not, however, distort the comparison of alternative solutions. All parameter values are converted to 2018 price levels (Official Statistics of Finland 2020).

We use the price from bleached sulfate pulp export prices from 2018 as the pulp prices (Natural Resources Institute Finland 2021). The price of electricity is the average wholesale baseload electricity price from 2018 (European Commission 2019a, 2019b, 2019c, 2019d). The price of heat energy, annual chemical costs, annual capital costs, and total labour costs are based on Korpunen (2012, 2015). The price of biosludge is estimated as a share of the Soilfood soil amendment prices (J. Joona, Soilfood Oy, personal communication, 13 November 2018). The amounts of pulp, lignin, biosludge, tall oil, and excess electricity and steam (sold outside) produced and pulpwood used are taken from the environmental impact assessment report of the Metsä Fibre Äänekoski pulp mill. This source allows us to describe the levels of the most important inputs and produced intermediate and final products (Metsä Fibre 2014; alternative plan VE1). ${ }^{5}$ If lignin is used in

\footnotetext{
${ }^{5}$ Lignin, tall oil, and biosludge are the main side streams of the pulp mill (Metsä Fibre 2014) that entail the trade-off we are focusing on: the use either for energy or biochemical products (cascading use). The environmental impact assessment report of the Metsä Fibre Äänekoski pulp mill (Metsä Fibre 2014, alternative plan VE1) states as other side streams: turpentine, product gas, and bark and dust. In alternative plan VE1 bark and dust are used to produce product gas, and turpentine is sold to companies that use it only for biochemical products.
} 
Table 2. Data and parameter values used in the profit maximization of a pulp mill.

\begin{tabular}{|c|c|c|c|}
\hline Description & Unit & Value & Source \\
\hline \multicolumn{4}{|l|}{ Production inputs } \\
\hline Wood raw material (pulpwood and wood chips) & $\mathrm{m}^{3}$ & 6780000 & Metsä Fibre 2014 \\
\hline Electricity use & GWh & 750 & Metsä Fibre 2014 \\
\hline Total labour costs & $€ /$ year & 18649673 & Korpunen 2015; Metsä Fibre 2014 \\
\hline Chemical costs & $€ /$ year & 34564830 & Korpunen et al. 2012 \\
\hline \multicolumn{4}{|l|}{ Prices of production inputs } \\
\hline Price of birch pulpwood & $€ / \mathrm{m}^{3}$ & 17.0 & Natural Resources Institute Finland 2021 \\
\hline Price of wood chips & $€ / \mathrm{m}^{3}$ & 29.5 & Korpunen 2010 \\
\hline Unit cost in mechanized harvesting (pulpwood) & $€ / \mathrm{m}^{3}$ & 13.4 & Natural Resources Institute Finland 2021 \\
\hline Overhead costs in harvesting and transportation & $€ / \mathrm{m}^{3}$ & 2.7 & Natural Resources Institute Finland 2021 \\
\hline $\begin{array}{l}\text { Unit costs of long-distance transportation of } \\
\text { industrial roundwood (rail transportation) }\end{array}$ & $€ / \mathrm{m}^{3}$ & 10.8 & Natural Resources Institute Finland 2021 \\
\hline Lignin & $\mathrm{t}$ & 75000 & Metsä Fibre 2014 \\
\hline Biosludge & $\mathrm{t}$ & 11000 & Metsä Fibre 2014 \\
\hline Tall oil & $\mathrm{t}$ & 60000 & Metsä Fibre 2014 \\
\hline Excess steam sold & GWh & 650 & Metsä Fibre 2014 \\
\hline Excess electricity & GWh & 750 & Metsä Fibre 2014 \\
\hline \multicolumn{4}{|l|}{ Prices of final product and side streams } \\
\hline Price of pulp & $€ / \mathrm{t}$ & 669 & Natural Resources Institute Finland 2021 \\
\hline Price of lignin & $€ / \mathrm{t}$ & 462 & Gosselink 2011 \\
\hline Price of biosludge & $€ / \mathrm{t}$ & 0.60 & Estimated using Soilfood prices ${ }^{a}$ \\
\hline Price of tall oil & $€ / \mathrm{t}$ & 441 & Eurostat $2018 a$ \\
\hline
\end{tabular}

${ }^{a}$ Soilfood is a company selling soil amendment material containing side streams from pulp mills.

energy production, its heat value is $7.22 \mathrm{MWh} /$ tonne $(1$ metric ton $(\mathrm{t})=1000 \mathrm{~kg}$ ) (Tomani et al. 2011), the heat value of biosludge is $0.69 \mathrm{MWh} / \mathrm{t}$, and the heat value of tall oil is $10.28 \mathrm{MWh} / \mathrm{t}$ (Statistics Finland 2018). The bioenergy sold outside is assumed to be produced at an efficiency ratio of $80 \%$ (Metsä Fibre 2014). The used wood raw material of the pulp mill consists of both pulpwood and wood chips, which is transported to the mill either by road or rail transport (Metsä Fibre 2014). ${ }^{6}$ The price of wood raw material is calculated as the weighted average price of pulpwood and wood chips (Korpunen 2010; Natural Resources Institute Finland 2021). The price of pulpwood (pine, spruce, and birch) and wood chips, the unit cost in mechanized harvesting of pulpwood, and the unit costs in harvesting and transportation of industrial roundwood are constant per cubic metre (Natural Resources Institute Finland 2021). However, both pulpwood $\left(x_{p}\right)$ and wood chips $\left(x_{w}\right)$ have increasing unit road transportation costs (Fjeld et al. 2021; Laitila et al. 2016). For pulpwood transported by rail, we assumed a constant unit transportation cost (Natural Resources Institute Finland 2021). Thus, we define the function for wood input costs as follows:

$$
\begin{array}{ll}
C_{\text {pulpwood(road) }}: & 34.34 \times x_{p}+0.0204 \times x_{p}^{1.3903} \\
C_{\text {pulpwood(rail) }}: & 45.16 \times x_{p} \\
C_{\text {wood chips }}: & 29.5 \times x_{w}+0.0522 \times x_{w}^{1.3558}
\end{array}
$$

\subsubsection{Use of inputs and profits from pulp production}

We start the analysis by simply calculating the profits of the pulp mill according to eq. 2 for a given level of inputs and production, reflecting the short-term choice of the mill. We assume that all lignin, biosludge, and tall oil are either sold as a side stream or used to produce energy in the pulp mill. ${ }^{7}$ Because the pulp mill produces more energy than it needs, the energy produced from lignin, biosludge, and tall oil can be sold.

Outcomes are reported in Table 3, including sensitivity analysis with respect to the side stream and energy prices when $6780000 \mathrm{~m}^{3}$ of wood raw material is used annually in the production process. Profits are higher when lignin and tall oil are sold as a side stream, even when we let the prices of side stream or sold heat energy vary. Given that both the price of biosludge sold as a side stream and the heat value of biosludge are low, the difference in profits between these alternative uses for this side stream is relatively small.

In the long term, the pulp mill can optimize the use of all inputs. We employ the Cobb-Douglas production function to describe the production technology of the pulp mill. The CobbDouglas production function is given by $\left(x, e_{p}\right)=A x^{\alpha} e_{p}^{\beta}$, where parameters $\alpha$ and $\beta$ describe the shares of production factors (wood raw material and energy) in the production of pulp. We calibrate the parameters $A, \alpha$, and $\beta$ using Matlab and the data reported in Table 2 . We calibrate the production function assuming the pulp mill neither produces energy from side streams nor sells it to a biochemical company. This produces the benchmark

\footnotetext{
${ }^{6}$ According to alternative plan VE1 in the environmental impact assessment report of the Metsä Fibre Äänekoski pulpmill, we assume that 59\% of wood raw material is pulpwood transported by road, $21 \%$ of wood raw material is pulpwood transported by rail, and $20 \%$ of wood raw material is wood chips transported by road (Metsä Fibre 2014).

${ }^{7}$ We acknowledge that it might not be feasible to use the same amount of side stream both in energy production or to sell it as a side stream in practice. However, this simplification allows us to compare these two alternative uses of side streams.
} 
Table 3. The short-term profits of the pulp mill when side streams are either sold to the biochemical company or used as energy.

\begin{tabular}{|c|c|c|c|c|c|c|}
\hline \multirow[b]{4}{*}{ Side stream } & \multicolumn{6}{|c|}{ Profits of the pulp mill (million $€ /$ year) } \\
\hline & \multicolumn{3}{|c|}{ Sold as a side stream } & \multicolumn{3}{|c|}{ Used as an energy source } \\
\hline & \multirow[b]{2}{*}{ Basic run } & \multicolumn{2}{|c|}{$\begin{array}{l}\text { Price of side } \\
\text { stream }\end{array}$} & \multirow[b]{2}{*}{ Basic run } & \multicolumn{2}{|c|}{$\begin{array}{l}\text { Price of } \\
\text { energy }\end{array}$} \\
\hline & & $-10 \%$ & $+10 \%$ & & $-10 \%$ & $+10 \%$ \\
\hline Tall oil & 419.6 & 416.9 & 422.2 & 409.4 & 407.8 & 411.0 \\
\hline Biosludge & 393.1 & 393.1 & 393.1 & 393.3 & 393.3 & 393.4 \\
\hline Lignin & 427.8 & 424.3 & 431.2 & 407.4 & 406.0 & 408.9 \\
\hline
\end{tabular}

of free disposal of waste in the firm's landfill as our benchmark. ${ }^{8}$ We compare the benchmark to two cases. First, the pulp mill produces energy from side streams and sells the produced extra energy. Second, we add the possibility of selling all side streams to the biochemical company. In both cases, the pulp mill freely chooses the use of inputs to optimize its profits. Pulp production produces steam as a side product, and the mill sells the excess steam, which is considered additional revenue similarly in all three cases.

Table 4 reports the results when the side stream to be allocated is tall oil. Under the postulated prices, allocating tall oil from the benchmark for energy or bio-products increases profits and the use of wood. The possibility to produce energy from tall oil increases profits by $4.3 \%$ relative to the benchmark. Allowing the possibility of selling tall oil to a biochemical company increases the profits even by 7.1\%. Looking at the sensitivity analysis, when the pulp price increases, the use of both wood and electricity increases as the profitability of the pulp production is higher. This is according to our analytical results (Table 1), suggesting that the impact of energy price on the use of wood and energy is ambiguous due to two opposing effects. The numerical model shows that the price effect on the use of wood is positive and on the use of energy negative. Increased profitability of wood in energy production increases the use of wood. As expected, the price of the side stream has a positive effect on both the use of wood and electricity. Similarly, the price of wood has a negative effect on the use of wood and electricity. ${ }^{9}$

Table 5 reports the results for lignin as the side stream. The possibility to produce energy from lignin increases profits by $3.8 \%$ relative to the benchmark. The possibility to sell lignin to a biochemical company increases the profits by $9.5 \%$ relative to the benchmark. The sensitivity analysis shows similar results as in the case of tall oil.

Table 6 reports the results for the case of biosludge. In this case, producing energy from biosludge increases profits by only $0.05 \%$ relative to the baseline. Furthermore, the possibility to sell biosludge to a biochemical company does not change the profits relative to the baseline because the price of biosludge as a sold side stream is low. It should also be noted that the amount of biosludge produced in the pulp mill is relatively low compared to the produced amounts of tall oil and lignin. These two features also explain our finding that the price of the side stream does not affect the use of wood and electricity. Sensitivity analysis provides similar effects as in the cases of tall oil and lignin.

Finally, Tables 4 and 5 show that relative to the baseline, the possibility of producing energy or selling tall oil and lignin to the bioproduct company increases the use of wood. In the case of biosludge, the use of wood does not significantly change. Both the long-run and short-run profits indicate that the profitability of side streams differs. First, the profits of the pulp mill are higher when tall oil and lignin are sold as side streams than when they are used in energy production. Second, the difference in profits of the pulp mill is relatively small between alternative uses of biosludge. Third, the long-run sensitivity results also indicate that changes with respect to the pulp price have the most significant effects on the optimal input use and profits. This result holds for all three products: tall oil, lignin, and biosludge.

Next, we focus on the biochemical company's optimal production decisions in the pine chemical industry, which represents the traditional use of pulp mill's side streams into high-valueadded chemical products.

\subsection{The cascading use of side streams: biochemical company}

Biochemical companies play an essential role in the forest bioeconomy. They produce high-quality products from side streams, thereby giving pulp mills a chance to get rid of their side streams profitably. However, data from biochemical production and prices from side streams are even scarcer than in the case of pulp mills. In this section, we focus on the pine chemical industry and examine the properties of the model numerically. We also employ them to illustrate the welfare effects of material shortages on the production of the biochemical company. This exemplifies the extreme impact the promotion of biodiesel might have on the production of higher-value chemical products via increasing raw material prices (Cashman et al. 2015).

\subsubsection{Data and parameters}

The biochemical company using tall oil produces tall oil rosin and tall oil fatty acids as the final products. We assume that the biochemical company buys tall oil and steam from the pulp mill. Suppose we assume that biochemical company uses $60000 \mathrm{t}$ of crude tall oil annually, based on Cashman et al. (2015). In that case, we can estimate the amount of tall oil used for tall oil rosin and tall oil fatty acids, produced amounts of final products, and the energy needed in the production process. Transportation and light fuel oil costs and steam provided to the pulp and paper mill are omitted here. The main production inputs and their prices, production amounts, and final products are presented in Table 7.

\subsubsection{The use of inputs and profits of the biochemical company}

We again use the Cobb-Douglas production function to characterize the production technology of the biochemical company. In the long term, the biochemical company can optimize the use of inputs in its production process. The Cobb-Douglas production function is given by $y=A x^{a} e_{p}^{b}$, where the factors $a$ and $b$ describe the shares of production factors (tall oil and energy) in the production of tall oil rosin and tall oil fatty acids. First, Table 8 reports the optimal production under the basic price of $441 € / t$ of crude tall oil. Then, these figures are compared to choices under higher input prices. It is, however, difficult to estimate how much the price increases due to decreased supply of raw material if the tall oil is increasingly used to produce biodiesel. Therefore, we postulate $10 \%$ and $20 \%$ increases in the input price of crude tall oil, mainly due to the assumption of increased transportation costs. Appendix Table A1 presents the sensitivity analysis with respect to changes in energy prices and the price of the final product.

From Table 8, if the price of crude tall oil increases by either $10 \%$ or $20 \%$, the reduction in the use of tall oil is significant. The use of energy inputs, production, and the profits also decrease. In light of these calculations, a biofuel policy that creates demand

\footnotetext{
${ }^{8}$ Using landfills is, in practice, an option for low-value waste. However, assuming free disposal is a simplification, as using the firm's own landfills entails some costs.

${ }^{9}$ In the sensitivity analysis, the change in wood prices is modelled as the change in the weighted average of pulpwood (birch, pine, and spruce) and wood chips.
} 
Table 4. Tall oil as a side stream and the profits and use of pulpwood for the pulp mill: baseline, the use for energy, or sale to a biochemical company.

\begin{tabular}{|c|c|c|c|c|c|c|c|c|c|}
\hline & \multicolumn{3}{|c|}{ Benchmark: no use of tall oil } & \multicolumn{3}{|c|}{ Tall oil for energy production } & \multicolumn{3}{|c|}{ Tall oil sold to the biochemical company } \\
\hline & $\begin{array}{l}\text { The wood raw } \\
\text { material used } \\
\left(1000 \mathrm{~m}^{3}\right)\end{array}$ & $\begin{array}{l}\text { Electricity used in } \\
\text { pulp production } \\
\text { (GWh) }\end{array}$ & $\begin{array}{l}\text { Profits, } \\
\text { million } \\
(€ / \text { year })\end{array}$ & $\begin{array}{l}\text { The wood raw } \\
\text { material used } \\
\left(1000 \mathrm{~m}^{3}\right)\end{array}$ & $\begin{array}{l}\text { Electricity used in } \\
\text { pulp production } \\
\text { (GWh) }\end{array}$ & $\begin{array}{l}\text { Profits, } \\
\text { million } \\
(€ / \text { year })\end{array}$ & $\begin{array}{l}\text { The wood raw } \\
\text { material used } \\
\left(1000 \mathrm{~m}^{3}\right)\end{array}$ & $\begin{array}{l}\text { Electricity used in } \\
\text { pulp production } \\
\text { (GWh) }\end{array}$ & $\begin{array}{l}\text { Profits, } \\
\text { million } \\
(€ / \text { year })\end{array}$ \\
\hline Basic run & 6780 & 750 & 393.1 & 7284 & 778 & 410.0 & 7627 & 796 & 421.2 \\
\hline \multicolumn{10}{|c|}{ Energy prices (electricity/heat), €/MWh } \\
\hline $42 / 30(-10 \%)$ & 6567 & 830 & 387.8 & 7001 & 857 & 402.6 & 7372 & 880 & 414.9 \\
\hline $52 / 36(+10 \%)$ & 7011 & 687 & 399.2 & 7594 & 715 & 418.3 & 7904 & 729 & 428.2 \\
\hline \multicolumn{10}{|c|}{ Side stream price, $€ / t$} \\
\hline $397(-10 \%)$ & - & - & - & - & - & - & 7536 & 791 & 418.2 \\
\hline $485(+10 \%)$ & - & - & - & - & - & - & 7719 & 801 & 424.2 \\
\hline \multicolumn{10}{|l|}{ Pulp price, $€ / t$} \\
\hline $602(-10 \%)$ & 5538 & 606 & 310.4 & 5957 & 629 & 324.2 & 6242 & 644 & 333.4 \\
\hline 736 (+10\%) & 8133 & 908 & 484.6 & 8728 & 941 & 504.9 & 9131 & 963 & 518.3 \\
\hline \multicolumn{10}{|c|}{ Price of wood raw material, $€ / \mathrm{m}^{3}$} \\
\hline$-10 \%$ & 7207 & 774 & 407.5 & 7757 & 803 & 425.4 & 8132 & 822 & 437.3 \\
\hline$+10 \%$ & 6388 & 728 & 379.6 & 6851 & 754 & 395.5 & 7164 & 771 & 406.0 \\
\hline
\end{tabular}

Table 5. Lignin as a side stream and the profits and use of pulpwood for the pulp mill: baseline, the use for energy, or sale to a biochemical company.

\begin{tabular}{|c|c|c|c|c|c|c|c|c|c|}
\hline & \multicolumn{3}{|c|}{ Benchmark: no use of lignin } & \multicolumn{3}{|c|}{ Lignin for energy production } & \multicolumn{3}{|c|}{ Lignin sold to the biochemical company } \\
\hline & $\begin{array}{l}\text { The wood raw } \\
\text { material used } \\
\left(1000 \mathrm{~m}^{3}\right)\end{array}$ & $\begin{array}{l}\text { Electricity used in } \\
\text { pulp production } \\
\text { (GWh) }\end{array}$ & $\begin{array}{l}\text { Profits, } \\
\text { million } \\
(€ / \text { year })\end{array}$ & $\begin{array}{l}\text { The wood raw } \\
\text { material used } \\
\left(1000 \mathrm{~m}^{3}\right)\end{array}$ & $\begin{array}{l}\text { Electricity used in } \\
\text { pulp production } \\
\text { (GWh) }\end{array}$ & $\begin{array}{l}\text { Profits, } \\
\text { million } \\
(€ / \text { year })\end{array}$ & $\begin{array}{l}\text { The wood raw } \\
\text { material used } \\
\left(1000 \mathrm{~m}^{3}\right)\end{array}$ & $\begin{array}{l}\text { Electricity used in } \\
\text { pulp production } \\
\text { (GWh) }\end{array}$ & $\begin{array}{l}\text { Profits, } \\
\text { million } \\
(€ / \text { year })\end{array}$ \\
\hline Basic run & 6780 & 750 & 393.1 & 7220 & 774 & 407.9 & 7918 & 811 & 430.6 \\
\hline \multicolumn{10}{|c|}{ Energy prices (electricity/heat), €/MWh } \\
\hline $42 / 30(-10 \%)$ & 6567 & 830 & 387.8 & 6946 & 854 & 400.7 & 7648 & 896 & 424.0 \\
\hline $52 / 36(+10 \%)$ & 7011 & 687 & 399.2 & 7519 & 711 & 415.9 & 8212 & 744 & 437.9 \\
\hline \multicolumn{10}{|c|}{ Side stream price, $€ / \mathrm{t}$} \\
\hline $416(-10 \%)$ & - & - & - & - & - & - & 7793 & 805 & 426.6 \\
\hline $508(+10 \%)$ & - & - & - & - & - & - & 8047 & 818 & 434.7 \\
\hline \multicolumn{10}{|l|}{ Pulp price, $€ / \mathrm{t}$} \\
\hline $602(-10 \%)$ & 5538 & 606 & 310.4 & 5903 & 626 & 322.5 & 6485 & 657 & 341.1 \\
\hline $736(+10 \%)$ & 8133 & 908 & 484.6 & 8652 & 937 & 502.3 & 9474 & 981 & 529.5 \\
\hline \multicolumn{10}{|c|}{ Price of wood raw material, $€ / \mathrm{m}^{3}$} \\
\hline$-10 \%$ & 7207 & 774 & 407.5 & 7687 & 799 & 423.2 & 8451 & 839 & 447.3 \\
\hline$+10 \%$ & 6388 & 728 & 379.6 & 6792 & 751 & 393.5 & 7431 & 786 & 414.8 \\
\hline
\end{tabular}




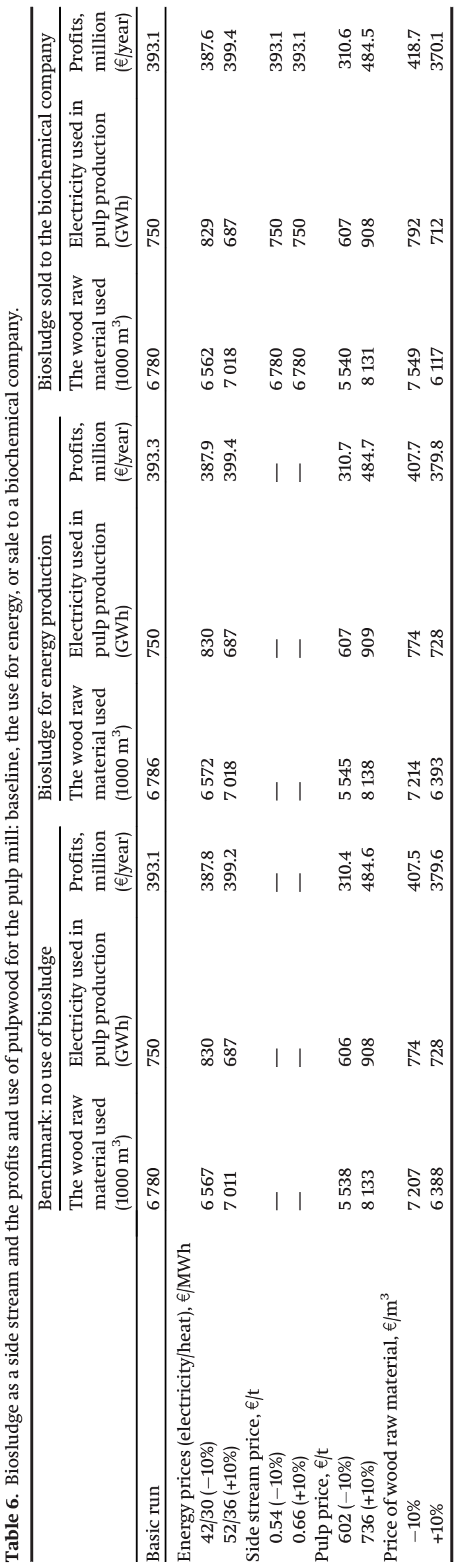

for tall oil via blending mandates provides a true challenge to biochemical companies in the tall-oil-using industry. Drawing on the results of Table 8 , we can estimate the welfare loss due to material shortage at the production and the need to import raw material at a higher price as illustrated in Fig. 2 (recall, the difference between $m^{*}$ and $m^{* * *}$ ). Suppose that biochemical company receives side streams from the pulp mill 30\%-40\% less than the optimal production would require. The welfare loss estimate is considerable, ranging from $555300 €$ to $877300 €$.

\section{Conclusions}

We examined the economic features of the forest bioeconomy as an industrial ecosystem consisting of traditional pulp mills and biochemical companies using side streams from pulp production in the vicinity of the pulp mill. Our analysis is unique in the literature. It focuses on the economic interaction between the companies and traces out the impacts of relative prices on the allocation of wood-based side streams between energy production and cascading use for biochemical products.

Analytically, we found that under perfect competition, the emerging industrial ecosystem uses more pulpwood than the traditional forest industry. Second, market imperfections showing up either in monopoly or monopsony behaviour lead to a lower cascading use of wood-based side streams and increased use of side streams in energy production. On the other side of the coin, imperfect competition decreases demand for pulpwood. Third, in the presence of a shortage in the supply of side streams or market power of the biochemical company, the production of bioproducts remains at a sub-optimal level.

The numerical forest bioeconomy model confirms that for the main side streams analyzed in this study, tall oil and lignin, bioeconomy with cascading use of wood promotes higher use of wood, implying higher harvesting levels of forests. By lowering forest sink, this would pose a challenge to climate change mitigation, which the transition to forest bioeconomy is expected to promote (Kalliokoski et al. 2020; Seppälä et al. 2019; Soimakallio et al. 2016). However, the effect of increased harvesting on biodiversity is less clear. It depends on multiple issues, such as the relative shares of thinnings versus final felling, the forest management regimes, and biodiversity policy.

We show that selling side streams is more profitable than energy production for the pulp mill, promoting the more efficient use of side streams in the case of tall oil and lignin. In contrast, profits from biosludge did not significantly differ between alternative uses due to low prices and produced amounts. These results align with previous studies as they find value-added biochemical products based on lignin and tall oil economically feasible and providing significant future potential (Aryan et al. 2019; Bajwa et al. 2019; Xu et al. 2021). Hassan et al. (2019) defined biosludge as a low-value side stream and estimated that only a small share of biosludge is used for economic purposes in Finland.

Our results have implications for the debate on EU policies promoting renewable energy targets (EU Directive 2015/1513). The pine chemicals industry has highly criticized these policies for favouring biodiesel production and increasing competition on crude tall oil. Aryan and Kraft (2020) estimate that the supply deficit of crude tall oil may be as high as $8 \%$ globally by 2030 . This material shortage would increase tall oil prices and decrease the pine chemical industry's profits and production levels. This does not follow the cascading principle of side stream use. The life cycle assessment studies by Cashman et al. (2015) and Aryan et al. (2019) did not find any additional climate benefits if crude tall oil is used in biodiesel production instead of current chemical production. Bauer et al. (2017) note that the EU has set clear targets for biofuels but has not set any targets for other bioproducts, such as biochemical and biomaterials. 
Table 7. Data and parameter values used in the profit maximization of a biochemical company.

\begin{tabular}{|c|c|c|c|}
\hline Description & Unit & Value & Source \\
\hline \multicolumn{4}{|l|}{ Production inputs } \\
\hline Crude tall oil & $\mathrm{t}$ & 36600 & Cashman et al. 2015; Metsä Fibre 2014 \\
\hline Purchased electricity & MWh & 6528 & Estimated based on Cashman et al. 2015 \\
\hline Purchased steam & MWh & 6121 & Estimated based on Cashman et al. 2015 \\
\hline Natural gas & MWh & 2528 & Estimated based on Cashman et al. 2015 \\
\hline Heavy fuel oil & $\mathrm{MWh}$ & 1520 & Estimated based on Cashman et al. 2015 \\
\hline \multicolumn{4}{|l|}{ Prices of production inputs } \\
\hline Price of tall oil & $€ / \mathrm{t}$ & 441 & Eurostat 2018a \\
\hline Price of electricity & $€ / \mathrm{MWh}$ & 47 & European Commission 2019a, 2019b, 2019c, 2019d \\
\hline Price of heat energy & $€ / \mathrm{MWh}$ & 33 & Korpunen 2015 \\
\hline Price of natural gas & $€ / M W h$ & 39 & Eurostat $2018 b$ \\
\hline Price of heavy fuel oil & $€ / \mathrm{MWh}$ & 44 & Statistics Finland 2019 \\
\hline \multicolumn{4}{|l|}{ Production amounts } \\
\hline Tall oil rosin & $\mathrm{t}$ & 16701 & Estimated based on Cashman et al. 2015 \\
\hline Tall oil fatty acids & $\mathrm{t}$ & 21031 & Estimated based on Cashman et al. 2015 \\
\hline \multicolumn{4}{|l|}{ Prices of final products } \\
\hline Price of tall oil rosin & $€ / \mathrm{t}$ & 1520 & Spekreijse et al. 2019 \\
\hline Price of tall oil fatty acids & $€ / \mathrm{t}$ & 1162 & Eurostat 2018a \\
\hline
\end{tabular}

Table 8. Profits, produced amounts, and use of production inputs of the biochemical company in the long-run optimum when the price of crude tall oil increases.

\begin{tabular}{lllll}
\hline & $\begin{array}{l}\text { Profits, million } \\
(€ / \text { year })\end{array}$ & $\begin{array}{l}\text { Production } \\
\text { amount }(\mathrm{t})\end{array}$ & $\begin{array}{l}\text { Use of tall } \\
\text { oil }(\mathrm{t})\end{array}$ & $\begin{array}{l}\text { Use of energy } \\
(\mathrm{MWh})\end{array}$ \\
\hline $\begin{array}{l}\text { Basic run } \\
\text { Crude tall oil price, } € / \mathrm{t}\end{array}$ & 33.00 & 37732 & 36600 & 16698 \\
$\quad$ & & & \\
$485(+10 \%)$ & $31.5(-5 \%)$ & $36013(-5 \%)$ & $31757(-13 \%)$ & $15937(-5 \%)$ \\
$529(+20 \%)$ & $30.2(-9 \%)$ & $34513(-9 \%)$ & $27898(-24 \%)$ & $15273(-9 \%)$ \\
\hline
\end{tabular}

Our analysis sheds new light on the slow development towards utilizing all side streams from pulp production, despite keen interest in 'biorefineries' (see, e.g., Bauer et al. 2017). We demonstrated that competitive input prices and a secure supply of raw material are crucial for biochemical company's profits - and indirectly also for the decision to invest in new bioproducts. This also includes a company's assessment of the potential market power of pulp mills. From the pulp mill's viewpoint, in turn, the profitability of different side streams, whether sold as a side stream or used in energy production, differs. Anticipating future demand and profits from bioproduct markets thus affect pulp mills' decisions. Finally, an additional source of uncertainty is provided by energy and climate policies, which are not always consistent, as the case of biofuel policy suggests.

The data used in the numerical application was gathered from different sources. Similarly, as in many quantitative studies on wood cascading, there are uncertainties concerning how detailed the data are (Jarre et al. 2020). Interestingly, though, our results concerning net profits (302-331 $€ / t$ ) are very close to Korpunen et al. (2012), who found that the net profits were $312 € / t$ to $334 € / t$ (2018 price level). Nevertheless, more and better data are needed for an analysis of all possible side streams. Also, more detailed technical data related to the pulp mill's processes would be highly valuable to develop the numerical model further. More information is also needed on the environmental and climate impacts of alternative uses of different side streams.

The most important contribution of this study is to offer a genuinely economic analysis of the forest bioeconomy as an industrial ecosystem. It complements the existing and more technically oriented models and provides a framework for incentive analysis. ${ }^{10}$ Our formal economic framework facilitates both analytical and numerical analysis of climate and other policy instruments. It can be flexibly made more complex and detailed either technologically, economically, or policy-wise. Therefore, it opens many avenues for future research. The role of market imperfections and policies correcting them shows up as an essential issue. Regarding the sustainability challenges, examination of the impacts of climate and circular economy instruments is urgently needed. The broader aspects of the forest bioeconomy, such as biodiversity or the role of sinks, were only shortly discussed in this study. Interesting questions for future work include broadening the established framework to forest biodiversity and land use, land-use change, and forestry (LULUCF) policies, as it is clear that the sustainability aspects of the forest bioeconomy need to be secured (see e.g., recent IPBES 2018; and IPCC 2019 reports) in order for the forest sector to fulfil its promise of being the renewable alternative to the fossilbased industry in a sustainable way.

\section{Competing interests}

The authors declare there are no competing interests.

\section{Acknowledgements}

This work is a part of the research consortium "Orchestrating sustainable user-driven bioeconomy: Policy, transformation and benefits" (Orbit), which is funded by the Strategic Research Council of the Academy of Finland (Grant No. 307481 Orbit). We thank two

\footnotetext{
${ }^{10}$ Recall, these models cover the supply chain design and optimization models (e.g., Mansoornejad et al. 2010; Elaradi et al. 2021; Machani et al. 2014) and techno-economical assessment models and process models (e.g., Mansoornejad et al. 2010; Dessbesell et al. 2018), process modelling and economic analysis (e.g., Huang et al. 2009, 2010).
} 
anonymous reviewers and the Editor for their insightful and constructive comments on the previous version of the paper.

\section{References}

Antikainen, R., Dalhammar, C., Hildén, M., Judl, J., Jääskeläinen, T., Kautto, et al. 2017. Renewal of forest based manufacturing towards a sustainable circular bioeconomy. Reports of the Finnish Environment Institute 13/2017. Finnish Environment Institute, Helsinki. Available from http://hdl.handle.net/10138/186080.

Aryan, V., and Kraft, A. 2020. The crude tall oil value chain: global availability and the influence of regional energy policies. J. Clean. Prod. 280: 124616. doi:10.1016/j.jclepro.2020.124616.

Aryan, V., Maga, D., and Kraft, A. 2019. Quantifying the impact of cascading use: a comparative integrated assessment of the European pine chemicals industry. J. Clean. Prod. 224: 766-778. doi:10.1016/j.jclepro.2019.03.240.

Bajwa, D.S., Pourhashem, G., Ullah, A.H., and Bajwa, S.G. 2019. A concise review of current lignin production, applications, products and their environmental impact. Ind. Crops Prod. 139: 111526. doi:10.1016/j.indcrop.2019.111526.

Bauer, F., Coenen, L., Hansen, T., McCormick, K., and Palgan, Y.V. 2017. Technological innovation systems for biorefineries: a review of the literature. Biofuels, Bioprod. Bioref. 11: 534-548. doi:10.1002/bbb.1767.

Cashman, S.A., Moran, K.M., and Gaglione, A.G. 2015. Greenhouse gas and energy life cycle assessment of pine chemicals derived from crude tall oil and their substitutes. Res. Anal. 20(5): 1108-1121. doi:10.1111/jiec.12370.

Christopher, L. 2013. Integrated forest biorefineries: current state and development potential. In Integrated Forest Biorefineries: Challenges and Opportunities. Edited by L. Christopher. The Royal Society of Chemistry. Green Chemistry, Vol. 18, pp. 1-66.

Culbertson, C., Treasure, T., Venditti, R., Jameel, H., and Gonzalez, R. 2016. Life cycle assessment of lignin extraction in a softwood kraft pulp mill. Nord. Pulp Pap. Res. J. 31(1): 30-40. doi:10.3183/npprj-2016-31-01-p030-040.

Dansereau, L.P., El-Halwagi, M., Chambost, V., and Stuart, P. 2014. Methodology for biorefinery portfolio assessment using supply-chain fundamentals of bioproducts. Biofuels, Bioprod. Biorefin. 8: 716-727. doi:10.1002/bbb.1490.

Daya, B.B., and Nourelfath, M. 2019. Sustainability assessment of integrated forest biorefinery implemented in Canadian pulp and paper mills. Int. J. Prod. Econ. 214: 248-265. doi:10.1016/j.ijpe.2018.06.014.

Dessbesell, L., Xu, C., Pulkki, R., Leitch, M., and Mahmood, N. 2017. Forest biomass supply chain optimization for a biorefinery aiming to produce high-value bio-based materials and chemicals from lignin and forestry residues: a review of literature. Can. J. For. Res. 47: 277-288. doi:10.1139/ cjfr-2016-0336.

Dessbesell, L., Yuan, Z., Hamilton, S., Leitch, M., Pulkki, R., and Xu, C.C. 2018. Bio-based polymers production in a kraft lignin biorefinery: technoeconomic assessment. Biofuels, Bioprod. Bioref. 12: 239-250. doi:10.1002/ bbb.1834.

Elaradi, M.B., Zanjani, M.K., and Nourelfath, M. 2021. Integrated forest biorefinery network design under demand uncertainty: a case study on Canadian pulp \& paper industry. Int. J. Prod. Res. [In press]. doi:10.1080/00207543.2021.1944688.

European Commission. 2019a. Quarterly report on European Electricity Markets. Volume 11, issue 1, 1/2018. Available from https://ec.europa.eu/energy/ sites/ener/files/documents/quarterly_report_on_european_electricity_markets_ q1_2018.pdf.

European Commission. 2019b. Quarterly report on European Electricity Markets, Volume 11, issue 2, 2/2018. Available from https://ec.europa.eu/energy/sites/ ener/files/documents/quarterly_report_on_european_electricity_markets_q2 2018.pdf.

European Commission. 2019c. Quarterly report on European Electricity Markets, Volume 11, issue 3, 3/2018. Available from https://ec.europa.eu/energy/ sites/ener/files/documents/quarterly_report_on_european_electricity_markets_ q3_2018.pdf.

European Commission. 2019d. Quarterly report on European Electricity Markets, Volume 11, issue 4, 4/2018. Available from https://ec.europa.eu/energy/sites/ ener/files/quarterly_report_on_european_electricity_markets_q4_2018_0.pdf.

European Parliament and of the Council. 2015. EU Directive 2015/1513 of the European Parliament and the Council of 9 September 2015 amending Directive 98/70/EC relating to the quality of petrol and diesel fuels and amending Directive 2009/28/EC on the promotion of the use of energy from renewable sources. Available from https://eur-lex.europa.eu/legal-content/EN/TXT/PDF/?uri= CELEX:02015L1513-20210701\&qid=1644843981831\&from=en.

Eurostat. 2018a. International trade statistics. Available from https://ec.europa.eu/ eurostat/data/database [accessed 8 May 2020].

Eurostat. 2018b. Gas prices for non-household consumers. Available from https:/ ec.europa.eu/eurostat/databrowser/view/nrg_pc_203/default/table?lang=en [accessed 28 November 2020].

Fjeld, D., Väätäinen, K., von Hofsten, H., Noreland, D., Callesen, I., and Lazdins, A. 2021. Costing models for road, rail and sea transport of roundwood. NB Nord.

Gan, J. 2013. Economic and policy aspects of integrated forest biorefineries. In Integrated Forest Biorefineries: Challenges and Opportunities. Edited by L. Christopher. The Royal Society of Chemistry. Green Chemistry, Vol. 18, pp. 67-79.
Giurca, A., and Späth, P. 2017. A forest-based bioeconomy for Germany? Strengths, weaknesses and policy options for lignocellulosic biorefineries. J. Clean. Prod. 153: 51-62. doi:10.1016/j.jclepro.2017.03.156.

Gosselink, R. 2011. Lignin as a renewable aromatic resource for the chemical industry. PhD Thesis, Wageningen University.

Hämäläinen, S., Näyhä, A., and Pesonen, H.-L. 2011. Forest biorefineries - a business opportunity for the Finnish forest cluster. J. Clean. Prod. 19: 1884-1891. doi:10.1016/j.jclepro.2011.01.011.

Hassan, M.K., Villa, A., Kuittinen, S., Jänis, J., and Pappinen, A. 2019. An assessment of side-stream generation from Finnish forest industry. J. Mater. Cycles Waste Manag. 21: 265-280. doi:10.1007/s10163-018-0787-5.

Hermansson, F., Janssen, M., and Svanström, M. 2019. Prospective study of lignin-based and recycled carbon fibers in composites through metaanalysis of life cycle assessments. J. Clean. Prod. 223: 946-956. doi:10.1016/j. jclepro.2019.03.022.

Hermansson, F., Janssen, M., and Svanström, M. 2020. Allocation in life cycle assessment of lignin. Int. J. Life Cycle Assess. 25: 1620-1632. doi:10.1007/s11367020-01770-4.

Hetemäki, L., Hanewinkel, M., Muys, B., Ollikainen, M., Palahí, M., and Trasobares, A. 2017. Leading the way to a European circular bioeconomy strategy. From Science to Policy 5. European Forest Institute.

Huang, H.-J., Lin, W., Ramaswamy, S., and Tschirner, U. 2009. Process modeling of comprehensive integrated forest biorefinery - an integrated approach. Appl. Biochem. Biotechnol. 154: 26-216. doi:10.1007/s12010-0088478-7. PMID:19165631.

Huang, H.-J., Lin, W., Ramaswamy, S., Al-Dajani, W.W., and Tschirner, U. 2010. Process modeling and analysis of pulp mill-based integrated biorefinery with hemicellulose pre-extraction for ethanol production: a comparative study. Bioresour. Technol. 101: 624-631. doi:10.1016/j.biortech.2009.07.092. PMID: 19767201.

Hurmekoski, E., Jonsson, R., Korhonen, J., Jänis, J., Mäkinen, M., Leskinen, P., and Hetemäki, L. 2018. Diversification of the forest industries: role of new wood-based products. Can. J. For. Res. 48: 1417-1432. doi:10.1139/cjfr-2018-0116.

IPBES. 2018. The IPBES assessment report on land degradation and restoration. In Secretariat of the intergovernmental science-policy platform on biodiversity and ecosystem services. Edited by L. Montanarella, R. Scholes, and A. Brainich. Bonn, Germany. doi:10.5281/zenodo.3237392.

IPCC. 2019. Summary for policymakers: climate change and land: an IPCC special report on climate change, desertification, land degradation, sustainable land management, food security, and greenhouse gas fluxes in terrestrial ecosystems. Edited by P.R. Shukla, J. Skea, E. Calvo Buendia, V. Masson-Delmotte, H.-O., Pörtner, et al. [In press]. Available from https:/| www.ipcc.ch/site/assets/uploads/2019/08/Edited-SPM_Approved_Microsite_FINAL. pdf [accessed 22 August 2020].

Jarre, M., Petit-Boix, A., Priefer, C., Meyer, R., and Leipold, S. 2020. Transforming the bio-based sector towards a circular economy - What can we learn from wood cascading? For. Policy Econ. 110: 101872. doi:10.1016/j. forpol.2019.01.017.

Jonsson, R. 2013. How to cope with changing demand conditions - the Swedish forest sector as a case study: an analysis of major drivers of change in the use of wood resources. Can. J. For. Res. 43: 405-418. doi:10.1139/cjfr-20120139.

Jonsson, R., Rinaldi, F., Pilli, R., Fiorese, G., Hurmekoski, E., Cazzaniga, N., et al. 2021. Boosting the EU forest-based bioeconomy: market, climate, and employment impacts. Technol. Forecast. Soc. Change, 163: 120478. doi:10.1016/j.techfore.2020.120478.

Kalliokoski, T., Bäck, J., Boy, M., Kulmala, M., Kuusinen, N., Mäkelä, A., et al. 2020. Mitigation impact of different harvest scenarios of Finnish forests that account for albedo, aerosols, and trade-offs of carbon sequestration and avoided emissions. Front. For. Glob. Change, 3: 562044. doi:10.3389/ffgc.2020.562044.

Kangas, H.-L., Lintunen, J., Pohjola, J., Hetemäki, L., and Uusivuori, J. 2011. Investments into forest biorefineries under different price and policy structures. Energy Econ. 33: 1165-1176. doi:10.1016/j.eneco.2011.04.008.

Korpunen, H. 2010. Sahauksen kustannuslaskenta. In Presentation at PUU-ohjelman Pienpuupäivä. Available from http://www.metla.fi/tapahtumat/ 2010/pienpuuseminaari/korpunen_mikkeli.pdf [accessed 22 May 2021]. [In Finnish.]

Korpunen, H. 2015. Activity-based costing method in forest industry — modelling the production and costs of sawing, the pulp and paper industry, and energy production. University of Helsinki. Dissertationes Forestales 203. doi:10.14214/ df.203.

Korpunen, H., Virtanen, P., Dahl, O., Jylhä, P., and Uusitalo, J. 2012. An activitybased cost calculation for a kraft pulp mill. Tappi J. 11(9): 19-27. doi:10.32964/ TJ11.9.19.

Kumar, A., Adamopoulos, S., Jones, D., and Amiandamhen, S.O. 2021. Forest biomass availability and utilization potential in Sweden: a review. Waste and Biomass Valorization, 12: 65-80. doi:10.1007/s12649-020-00947-0.

Laitila, J., Asikainen, A., and Ranta, T. 2016. Cost analysis of transporting forest chips and forest industry by-products with large truck-trailers in Finland. Biomass and Bioenergy. 90: 252-261. doi:10.1016/j.biombioe.2016.04.011.

Lundmark, R., and Olsson, A. 2015. Factor substitution and procurement competition for forest resources in Sweden. Int. J. Prod. Econ. 169: 99-109. doi:10.1016/j.ijpe.2015.07.029. 
Lundmark, R., Lundgren, T., Olofsson, E., and Zhou, W. 2021. Meeting challenges in forestry: improving performance and competitiveness. Forests, 12: 208. doi: $10.3390 /$ f12020208.

Machani, M., Nourelfath, M., and D'Amours, S. 2014. A mathematicallybased framework for evaluating the technical and economic potential of integrating bioenergy production within pulp and paper mills. Biomass Bioenergy, 63: 126-139. doi:10.1016/j.biombioe.2014.02.024.

Majumdar, I., Campbell, K.A., Maure, J., Saleem, I., Halasz, J., and Mutton, J. 2017. Forest bioeconomy in Ontario - a policy discussion. For. Chron. 93(1): 21-31. doi:10.5558/tfc2017-007.

Mansoornejad, B., Chambost, V., and Stuart, P. 2010. Integrating product portfolio design and supply chain design for the forest biorefinery. Comput. Chem. Eng. 34: 1497-1506. doi:10.1016/j.compchemeng.2010.02.004.

Mansoornejad, B., Pistikopoulos, E.N., and Stuart, P.R. 2013. Scenario-based strategic supply chain design and analysis for the forest biorefinery using an operational supply chain model. Int. J. Prod. Econ. 144: 618-634. doi:10. 1016/j.ijpe.2013.04.029.

Metsä Fibre, O.Y. 2014. Äänekosken biotuotetehtaan ympäristövaikutusten arviointiselostus. Available from www. ymparisto.fi/aanekoskenbiotuotetehdasYVA. [In Finnish.]

Mohammadi, A., Sandberg, M., Venkatesh, G., Eskandari, S., Dalgaard, T., Joseph, S., and Granström, K. 2019a. Environmental analysis of producing biochar and energy recovery from pulp and paper mill biosludge. J. Ind. Ecol. 23: 1039-1051. doi:10.1111/jiec.12838.

Mohammadi, A., Sandberg, M., Venkatesh, G., Eskandari, S., Dalgaard, T., Joseph, S., and Granström, K. 2019b. Environmental performance of end-of-life handling alternatives for paper-and-pulp-mill sludge: using digestate as a source of energy or for biochar production. Energy, 182: 594-605. doi:10.1016/j.energy.2019.06.065.

Moring, H., Laukkanen, T., and Dahl, O. 2013. Metsäteollisuuden jätevesilietteiden käsittely- ja hyötykäyttövaohtoehdot. In Vesitalous 1/2013. [In Finnish.]

Nabuurs, G.-J., Delacote, P., Ellison, D., Hanewinkel, M., Lindner, M., Nesbit, M., et al. 2015. A new role for forests and the forest sector in the EU post-2020 climate targets. From Science to Policy 2. European Forest Institute.

Natural Resources Institute Finland. 2021. Statistics database, Forest Statistics. Available from http://stat.luke.fi/en [accessed 22 May 2021].

Official Statistics of Finland. 2020. Producer price indices. Appendix Table 2. Producer Price Indices 1949=100, March 2020. Helsinki: Statistics Finland. Available from http://www.stat.fi/til/thi/2020/03/thi_2020_03_2020-04-24_ tau_002_en.html [accessed 25 April 2020].

Ollikainen, M. 2014. Forestry in bioeconomy - smart green growth for the humankind. Scand. J. For. Res. 29(4): 360-366. doi:10.1080/02827581.2014. 926392.

Pöykiö, R., Watkins, G., and Dahl, O. 2018. Characterization of primary and secondary wastewater treatment sludge from a pulp and board mill complex to evaluate the feasibility of utilization as a soil amendment agent and a fertilizer product. J. Bioresour. Bioproducts, 3(3): 88-95. doi:10.21967/jbb.v3i3.174.

Priefer, C., Jörissen, J., and Frör, O. 2017. Pathways to shape the bioeconomy. Resources, 6(1): 10. doi:10.3390/resources6010010. PMID:33490586.

Purkus, A. 2017. Towards a sustainable innovation system for the German wood-based bioeconomy: Implications for policy design. J. Clean. Prod. 172: 3955-3968. doi:10.1016/j.jclepro.2017.04.146.

Secchi, M., Castellani, V., Orlandi, M., and Collina, E. 2019. Use of lignin sidestreams from biorefineries as fuel or co-product? Life cycle analysis of bioethanol and pulp production processes. BioResources, 14(2): 4832-4865.

Seppälä, J., Heinonen, T., Pukkala, T., Kilpeläinen, A., Mattila, T., Myllyviita, T., et al. 2019. Effect of increased wood harvesting and utilization on required greenhouse gas displacement factors of wood-based products and fuels. J. Environ. Manage. 247: 580-587. doi:10.1016/j.jenvman.2019.06.031. PMID:31260924.

Söderholm, P., and Lundmark, R. 2009. The development of forest-based biorefineries: implications for market behaviour and policy. For. Prod. J. 59: 6-16.

Soimakallio, S., Saikku, L., Valsta, L., and Pingoud, K. 2016. Climate change mitigation challenge for wood utilization - the case of Finland. Environ. Sci. Technol. 50: 5127-5134. doi:10.1021/acs.est.6b00122. PMID:27074531.

Spekreijse, J., Lammens, T., Parisi, C., Ronzon, T., Vis, M. 2019. Insights into the European market for bio-based chemicals. Analysis based on ten key product categories JRC Science for Policy Report. Publications Office of the European Union, Luxembourg. doi:10.2760/739561.

Statistics Finland. 2018. Fuel classification 2018. Available from http://www.stat.fi/. Statistics Finland. 2019. Energy prices 2019. Available from http://www.stat.fi/.

Temmes, A., and Peck, P. 2020. Do forest biorefineries fit with working principles of a circular bioeconomy? A case of Finnish and Swedish initiatives. For. Policy Econ. 110: 101896. doi:10.1016/j.forpol.2019.03.013.

Thonemann, N., and Schumann, M. 2018. Environmental impacts of woodbased products under consideration of cascade utilization: a systematic literature review. J. Clean. Prod. 172: 4181-4188. doi:10.1016/j.jclepro.2016.12.069.

Tomani, P., Axegård, P., Berglin, N., Lovell, A., and Nordgren, D. 2011. Integration of lignin removal into a kraft pulp mill and use of lignin as biofuel. Cellul. Chem. Technol. 45(7-8): 533-540.

Volama, J. 2012. Teknologiaselvitys. Ligniini teollisessa valmistuksessa ja sen kaupalliset mahdollisuudet. Julkaisu 3/2012. Available from http://biosaimaa. fi/wp-content/uploads/2012/11/Ligniiniselvitys final.pdf. [In Finnish.]

Wenger, J., and Stern, T. 2019. Reflection on the research on and implementation of biorefinery systems - a systematic literature review with a focus on feedstock. Biofuels, Bioprod. Bioref. 13: 1347-1364. doi:10.1002/bbb.2021.

Wenger, J., Haas, V., and Stern, T. 2020. Why can we make anything from lignin except money? Towards a broader economic perspective in lignin research. Curr. For. Rep. 6: 294-308. doi:10.1007/s40725-020-00126-3.

Winkel, G. (ed) 2017. Towards a sustainable European forest-based bioeconomy assessment and the way forward. What Science Can Tell Us 8. European Forest Institute.

Xu, C.C., Dessbesell, L., Zhang, Y., and Yuan, Z. 2021. Lignin valorization beyond energy use: has lignin's time finally come? B, Bioprod. Biofuels Bioref. 15: 32-36. doi:10.1002/bbb.2172.

\section{Appendix A}

Table A1. Profits and use of production inputs of the biochemical company in the long-run optimum when the prices of energy and final product vary.

\begin{tabular}{llll}
\hline & $\begin{array}{l}\text { Profits, million } \\
(€ / \text { year })\end{array}$ & $\begin{array}{l}\text { Use of tall } \\
\text { oil }(\mathrm{t})\end{array}$ & $\begin{array}{l}\text { Use of energy } \\
(\mathrm{MWh})\end{array}$ \\
\hline $\begin{array}{l}\text { Basic run } \\
\text { Energy price, } € / \mathrm{MWh}\end{array}$ & 33.00 & 36600 & 16698 \\
$\quad 36(-10 \%)$ & 33.07 & 36679 & 18593 \\
$\quad \begin{array}{l}44(+10 \%) \\
\text { Price of the final } \\
\text { product, } € / \mathrm{t}\end{array}$ & 32.93 & 36530 & 15150 \\
$\begin{array}{l}1188(-10 \%) \\
1452(+10 \%)\end{array}$ & 28.15 & & \\
\hline
\end{tabular}

